\title{
GEOGRAPHICAL ANALYSIS OF THE IMPACT OF THE RELIEF ON THE DEVELOPMENT OF AGRICULTURE IN BOSNIA AND HERZEGOVINA: THE CASE STUDY OF USKOPALJSKA VALLEY
}

\author{
Gekić H., Bidžan-Gekić A., Doctors of Geographical Sciences, Senior Teaching Assistants \\ Department of Geography, Faculty of Science, University of Sarajevo, Sarajevo, \\ Bosnia and Herzegovina \\ E-mail: hgekic@gmail.com, aidabidzan@gmail.com
}

\begin{abstract}
Relief and agriculture are synchronized with each other, and it is obvious that for the agricultural geography of Bosnia and Herzegovina relief is one of the major conditions that affects different crops. The paper discusses the impact of relief on the development of agriculture in Uskopaljska valley mainly through geographical analysis of hypsometric and slope structure, exposure of sides and relief energy. Analysis of the characteristics of the relief enabled us to extract zones with different conditions for agricultural development. This analysis is very useful for agricultural planning and management in Uskopaljska valley. Area of Uskopaljska valley is not a homogeneous in respect of topography, slope, temperature and other resource endowments. An effort in this paper is done to explore and understand main relief processes.
\end{abstract}

\section{KEY WORDS}

Hypsometry, slope, exposure, relief energy, agricultural land use, crops.

Analysis and evaluation of geographical position represents an important factor for understanding of genesis, development, and function of any kind of area. Geographical position of the Uskopaljska valley has the following characteristics: it is situated in the Northern Hemisphere, in the field with geographic coordinates $43^{\circ} 51^{\prime}$ and $44^{\circ} 15^{\prime}$ North latitude, and between $17^{\circ} 16^{\prime}$ and $17^{\circ} 51^{\prime}$ East longitude. According to data acquired from the meteorological station of Bugojno, this area belongs to pre-mountain moderate continental climate type or, according to Kepen's Climate Classification, this municipality's region is dominated by Cfb climate (moderate warm and wet climate with warm summer), while in the mountain areas especially in the east, northeast and west, is presented Cfc climate as well (moderate warm and wet climate with fresh summer). On high mountain system of Vranica Dfb and ET climate are present. The main hydrographic skeleton of the Uskopaljska Valley area is presented with the Vrbas River and its tributaries.

Political-geographically, the Uskopaljska valley is situated in the state of Bosnia and Herzegovina, the entity of the Federation of Bosnia and Herzegovina, and within it, in the Central Bosnian Canton. Regional-geographically, it belongs to the Mountain-Valley macroregion, and the Upper Vrbas-Pliva mesoregion of Bosnia and Herzegovina. In Uskopaljska valley there are three municipalities: Bugojno (34.559 population), Donji Vakuf (14.739 population) and Gornji Vakuf-Uskoplje (22.304 population). By roads, Uskopaljska Valley is almost equally away from the cities of Banja Luka, Sarajevo, Mostar, and Split (around $140 \mathrm{~km}$ ). The total length of border of Uskopaljska valley towards the neighbouring municipalities is $259 \mathrm{~km}$ and in those borders the Uskopaljska valley around 1.087,2 square kilometers in area. According to the Census 2013 in Uskopaljska Valley lives 71.602 people [8]. Comparing the process of urbanization among the municipalities of the Uskopaljska valley shows that urbanization was most intense in Bugojno. One of the causes of such situation is much more intensive industrialization of Bugojno which has contributed to deagrarization [9].

Terrain slope is one of the major geomorphological aspects that affects the agricultural production of area. Effects of terrain slope on agricultural production can be indirect and direct. The most notable direct impact of terrain slope is in the form of limitations for 
cultivation, while indirect effects are pedo-geomorphologic and climate modifications including the position of water tables, soil and drainage development. The influence of relief on the deployment and structure of agricultural production is varied. The immediate effect of the relief is related primarily to the manner of processing and use of land, the possibility of irrigation and intensity of various recent geomorphologic processes and collateral for modifying climate, modification of vegetation and soil cover and other natural conditions [4].

\section{MORPHOLOGICAL SITES}

Initial relief formed by tectonic movements and volcanic activity is further shaped and broke down under the influence of lake abrasion, fluvial processes and decomposition processes and plowing rocky ground. Thus formed landforms provide different benefits for agriculture. As this paper is about Uskopaljska valley in the broader sense, as special relief units the following can be distinguished:

1. Alluvial plains and alluvial terraces that make up the bottom of the valley;

2. Depression hills, and within it:

a) depression hills in lake sediments which includes inter-valley inclines between the Volušnica, Čehajićka river, Drvetinska river, Vileški stream and Bistrica in the east and the Semešnica and Prusačka river, Lubovo, Poričnica and Veseočica and Gračanica in the west; b) depression hills in crystalline schists is mostly widespread in the northwestern, southwestern, northeastern and southeastern periphery of the valley;

3. Mountain brim consisting slopes of Radalj, Komara, Kalina, Rudina, Radovan mountain, Vranica and Zec mountain, Makljen, Raduša, Stožer, Šuljaga, Semešnica to the southern slopes of Ravna Gora [7].

The valley of the river Vrbas in this region has the dinaric direction. It is cut in the contact zone between Mesozoic limestone, Paleozoic shales in northeast and high karst zone in the southwest. The space of Uskopaljska Valley represents contact zone between two of the zone, and it extends from Gornji Vakuf through Bugojno and Donji Vakuf. It is in fact intermountain depression. Uskopaljska valley, as a form of relief in the narrow sense, is one of the medium-sized valleys in Bosnia and Herzegovina with an area of about 134 square kilometers and an average length of about $27 \mathrm{~km}$. Otherwise, the depression itself has a composite character, and consists of three parts: Gornji Vakuf expansion, Bugojno valley and Donji Vakuf expansion.

Gornji Vakuf expansion, as erosion expansion is characterized by rocks of different ages. At the top of the valley, where the Vrbas River exceeds downstream from the gorge into the expansion, is situated the town of Gornji Vakuf $(670 \mathrm{~m})$. The right side of the Vrbas here is built of clastic and foliated rocks as well as marble dolomite of Paleozoic age. The slopes on this side have large steeps and height as well as strong vertical and realtively dense horizontal dispersion that simultaneously causes processes of land sliding, attrition, collapse and splitting. Besides, significant are the karst surface and underground phenomena as well as karst hydrography.

The left side of the Vrbas in the area of Gornji Vakuf expansion is build out of schistose- clastic series of lower triassic and carbonate facies of Middle and Upper Triassic, and in the lowest part are lake molasses. Significant are also karst phenomena, sandbanks and gullies, as well as karst hydrography. Significant tributaries in this part of the Vrbas are: Krupa and Bistrica on the right and Voljički stream and Trnovača on the left side.

The area next to the Vrbas is marked by alluvial plains and low accumulative terraces. Since here the erosion took place in several stages, in addition to lower gravel, significant are more rocky terraces, too. The alluvial plain is not very wide and is sporadically scattered across the terraces. Along the outer edge of this part of the valley are slopes interspersed by surfaces emerged by denudation of Pliocene and Quaternary age.

Downstream from the Gornji Vakuf expansion, the valley narrows from the mouth of the Bistrica to Vileški stream into the Vrbas (width of 2-3 km) and then again the erosion expansion appears in molasse layers of small resistance. This area is designated as the Bugojno valley. A narrow part of this valley is built of Neogene molasse, limestone and 
dolomite of Triassic age while Neogene sediments are most pronounced in the wider part. For the erosion expansion of the Bugojno valley typical are the Vrbas meanders through alluvial, talus and proluvial deposits that are caused by the disorder of deposits and their slightly sinking in the central parts. The average width of this part of the Uskopaljska valley is about $9 \mathrm{~km}$. Around the mouth of the rivers on the part of the Uskopaljska valley, visibility of alluvial plains is increased. The erosion has caused the creation of two terraces, where the main is at about $10 \mathrm{~m}$ above the Vrbas and there is, in addition to other settlements, the town of Bugojno.

The slopes are continuing on the terraces, with light crossings, primarily those that are subject to leaching, dredging and sliding, and then the slopes subject to dropping out, collapse and splitting. They have significant agricultural potential.

Downstream of the Bugojno valley, the erosion expansion continues and passes into the area of Donji Vakuf. That is the northwest part of Uskopaljska valley in the narrow sense where there is the city of Donji Vakuf. Denudation and erosion of sediments of the boundary areas have caused the emergence of erosion expansion. Alluvium of this area is quite powerful and it is increased by the confluence of two major tributaries: Prusački and Oborački streams. Then, the alluvium slightly changes into the terraces that are 8-10 m above the Vrbas river. In the terrace building are significant fluvial sediments, and there are also expressed river bed alluvium, flood alluvium and alluvium oxbow.

Terraces gradually transform into slopes that are high up and cut by deep vallies. They are built by limestones, dolomites, conglomerates, where notable are attrition, sloughing, and on other rocks also sliding which causes the formation of loamy cover. These covers mitigate the transitions between terraces and pediments and between the valley slopes. Apart from river beds, especially of the Candian River and Volušnica, there occur infertile gravel-sand layers .

The area of the Uskopaljska valley is extremely suitable for crop production, but is also rich in forest areas which are located on the sides of the mountain rim and rich grass fields. From the aspect of agricultural production, alluvial plains are the most important form of relief in the Uskopaljska valley. Alluvial plains of the rivers are characterized by favorable structure of slope (slopes of $0-3^{\circ}$ ) and unexposed exposure. Shallow phreatic groundwater (depth to 3$10 \mathrm{~m}$ ) allows relatively easy irrigation of agricultural crops. The alluvial plains of rivers are related to fluvial hydromorphic soils of high production capacity. Therefore, these forms of relief are related mostly to intensive agricultural production, and even the greatest concentration of human activity.

The alluvial terraces are another important form of relief for agricultural production. In terms of value, river terraces are slightly behind river alluvial plains. This form of relief is characterized by slope gradients to $6^{\circ}$, unexposed and southern exposure. In relation to the alluvial plain, river terraces are located beyond the reach of underground and flood waters. To them are related types of soil with heavy mechanical composition and unfavorable waterair properties (vertisol, eutric cambisol, pseudogley etc.). Nevertheless, river terraces are suitable for growing most crops.

The foothill of the bottom and depression perimeter makes depression hills in lake sediments. They have the character of erosive relief. On the edge, in some places it reaches up to $600 \mathrm{~m}$ above sea level. In terms of value, depression hills in lake sediments are slightly behind the alluvial plains and river terraces. It features good exposure and side slopes of 6$12^{\circ}$. The dominant soil types are eutric cambisols. In the current deployment of agricultural production this part of depression hills, besides arable, is related to the areas under orchards.

Depression hills in crystalline schists also includes the valley perimeter to about $700 \mathrm{~m}$. From the aspect of agricultural production, mild relief forms and slopes of inclines of $6-12^{\circ}$ as well as greater depth of soil cover make this whole relief much more suitable for agriculture in relation to the mountain brim. However, in terms of benefits, it lags behind the depression hills in lake sediments. In addition to the meadows and orchards, the region is represented by arable land. 
Moving from the depression area to the east and west, the terrain gradually rises so that the mountain areas are represented in the east, west and south and form the perimeter of the valley. They have Dinaric direction. The mountains that surround the valley are of different ages. Younger Triassic mountains are represented in the west and are of smaller height than older Paleozoic ones in the east. These mountain areas are less populated and there are mainly population engaged in intensive livestock husbandry. Mountain ranges are mutually separated by plateaus and surfaces. The entire mountain range in the southwest, west and northwest which begins with Makljen and Raduša, to the southwest, and ends with south slopes of Ravna Gora in the northwest makes the unbroken chain of mountain ranges which are sparsely populated or uninhabited. The limiting factor of population in this area is also a great distribution of karst. Deep mountainous interior is uninhabited.

Moving from this mountain belt to the east, there are numerous independent ranges and ridges with elevations up to $1500 \mathrm{~m}$ which further complicate the development of settlements in the west. Besides massifs with the height of over 1,000 meters, in the western part there are still quite small isolated mountain areas with the height up to $1000 \mathrm{~m}$, which create a transition to the intermountain surfaces and floors that are widely represented in this area.Surfaces and plateaus are of the average altitude from 800 to $1100 \mathrm{~m}$ and are more represented in the western part. Many of them are spatially small and the largest is located in the east, Ravno Rostovo. Ravno Rostovo has an area of about 4 square kilometers, the average length of about $2.5 \mathrm{~km}$ and the width of about 1.5 square kilometers. It is of Paleozoic age built from biotite quartzdiorite. Almost $70 \%$ of the area are pastures.

From the surfaces in the western part what should be mentioned are Porička meadow and Hotigošće. The surface of Porička meadow has an average altitude of about 900 meters, it makes the right side of catchment of the river Poričnica that is the left tributary of the Vrbas. It has an area of about 3 square kilometers, with an average length of about $1.5 \mathrm{~km}^{2}$ and a width of $2 \mathrm{~km}^{2}$. The direction is northwest-southeast. It is of Triassic age. It is anhydrous and also filled with numerous sinkholes. It is mostly under pastures and dense evergreen forests.

The Hotigošće surface is one of the largest surfaces of the western part with an area of 2.7 square kilometers and an average height of about $1000 \mathrm{~m}$. It makes the left side of catchment of the river Mračajka and the upper flow of Duboka river. The direction is southwest-northeast. It is built of Triassic limestone and dolomite. It has numerous coves and sinkholes. This plateau today is related to intensive fruit production, especially berries. The areas of the plateau do not have permanent residents but there are periodic livestock settlements erected during the summer.

Northern parts of the Uskopaljska valley, in a broader sense, are presented by medium-high mountains starting from the southern slopes of Ravna Gora in the west to Radalj mountain in the east. On the south is Komar mountain $(927 \mathrm{~m})$, and out of other mountains there stand out Kalin $(1,530 \mathrm{~m})$, Rudina $(1,385 \mathrm{~m})$ and the highest mountain morphostructure of this area, Vranica mountain $(2,110 \mathrm{~m})$. Vranica is the largest mountain morphostructure in this area. Its borders are framed by the Vrbas River valley and its tributary Bistrica and the Fojnica river. The morphostructural core of Vranica belongs to the oldest geological formations marked on geological maps as Silurian-Devonian. To the south across Makljen, the mountain range of Paleozoic age continues to the east on Slima (north of Debelo Brdo 1,321 m, and Kalac 1,307 m), north to the village of Mejnik, upstream along the Tušnica river in the north-east of Klisac, Košara, Gorača, Zeleni Vrh, Jašarovo hill, Smrčevica, and ending with the Vitreuša peak on Vranica mountain, 1,919 m.

The mountain circumference surrounding the Uskopaljska valley to the east, south and west is rugged in places by deeply incised river valleys. This spatial unit is characterized by severe forms of relief with dominant slopes over $20^{\circ}$. Therefore, the preserved remains of spacious areas and valley expansions are almost the only agricultural areas in the relief. The thinned pedological cover (rankers, distric cambisols) has very scarce manufacturing capabilities. The mountain circumference is predominantly under natural grassland and forest vegetation. From the aspect of agricultural production, this relief unit is suitable for livestock. 


\section{MORPHOMETRIC CHARACTERISTICS OF THE RELIEF}

Agriculture, especially crop production, is largely determined by morphometric characteristics of the relief. Analysis of morphometric characteristics has been performed using topographic maps at scales of 1: 25,000 with the help of Geographic Information System (GIS). From morphometric characteristics of the relief significant for the deployment and structure of agricultural production, in particular were analyzed: hypsometric structure, slope structure, slope exposition and relief energy.

Hypsometric structure. Hypsometric structure reflects vertical diversity of the relief. It is in the Uskopaljska valley, in a broader sense, significant. The height difference between the highest (Nadkrstac, Vranica 2,110 m) and the lowest point (at the exit of the Vrbas River from the area of Uskopaljska valley $420 \mathrm{~m}$ ) is as high as $1,690 \mathrm{~m}$. However, the vertical diversity of the bottom of the valley, i.e. hypsometrical zones attractive for intensive agricultural production is moving to $200 \mathrm{~m}$.

With the rise of sea level, there are changes not only in zonal but also azonal natural conditions. Therefore, it is necessary to establish an upper altitude limit of rational crop agricultural production. The upper limit is based on the thermal properties of significantly altered morphometric and soil conditions, set at about $750 \mathrm{~m}$ above sea level, above which are scarce arable land. The areas above 750 meters are predominantly covered with forest and grass vegetation.

The entire area of the Uskopaljska valley can be divided into three characteristic hypsometric zones important for agricultural production:

1. The hilly zone with the domination of alluvial plains $420-600 \mathrm{~m}$ above sea level, covers approximately $7.35 \%$ of the observed area. This area includes the alluvial plain of the rivers, river terraces and most of the hills built in lake sediments and smaller parts of hills built in crystalline schists. The mouth of the river Gračanica is a kind of southern height border towards the following hypsometric level. This zone is related to intensive agricultural production in the Uskopaljska valley. Favorable slope structure favorable climate, soil and other natural conditions in this zone allow diverse crop production. The share of arable land in this area has been significantly reduced by expanding urban settlements of Bugojno and Donji Vakuf.

2. The hilly zone with the dominance of depression hills covers altitudes from 601 to $750 \mathrm{~m}$ above sea level. It closely surrounds the previous zone and significantly expands to the south up to Voljevac. Somewhat milder forms of relief are especially characteristic of the western and southern part. It covers an area of about 170.2 square kilometers which is $15.6 \%$ of the total observed area. From the aspects of agricultural production, hypsometric zone of $601-750 \mathrm{~m}$ is characterized by somewhat less favorable natural conditions. However, for greater distribution of agricultural land, this zone is characterized by intensive agricultural production of the previous zone, especially in the area of Gornji Vakuf expansion. In the milder forms of relief, there is present crop-fruit production, while the inclines are with steeper slopes under orchards and natural grasslands. Selection of agricultural crops is very varied (corn, potatoes, cabbage). This zone is characterized by a favorable structure of the slope angle (even $54 \%$ of the space is with inclination to $6^{\circ}$ ) (figure 1 ).

3. The mountain zone extends at altitudes above $750 \mathrm{~m}$ and occupies about $77 \%$ of the observed area. Except in the far north where the Vrbas river leaves the of space Uskopaljska valley, this zone completely surrounds the previous zone. Deteriorated environmental conditions hinder the development of intensive agricultural production. Mostly it is covered with natural grasslands and forest vegetation, while the arable land and the area under orchards occur only sporadically. The height in the southeast are reaching over 2,000 m.

Very significant are the effects of increase in relative altitude in the Uskopaljska valley which are: reducing the temperature, increasing precipitation, increased wind speed, soil depletion, rugged relief. Temperature decreases with increasing altitude as a consequence of thinning the air that has a low content of carbon dioxide, moisture and other particles. Consequently, the sun's rays pass through the air with weaker warming effect and a high proportion reaches the surface on the mountain tops that rapidly heat up. 


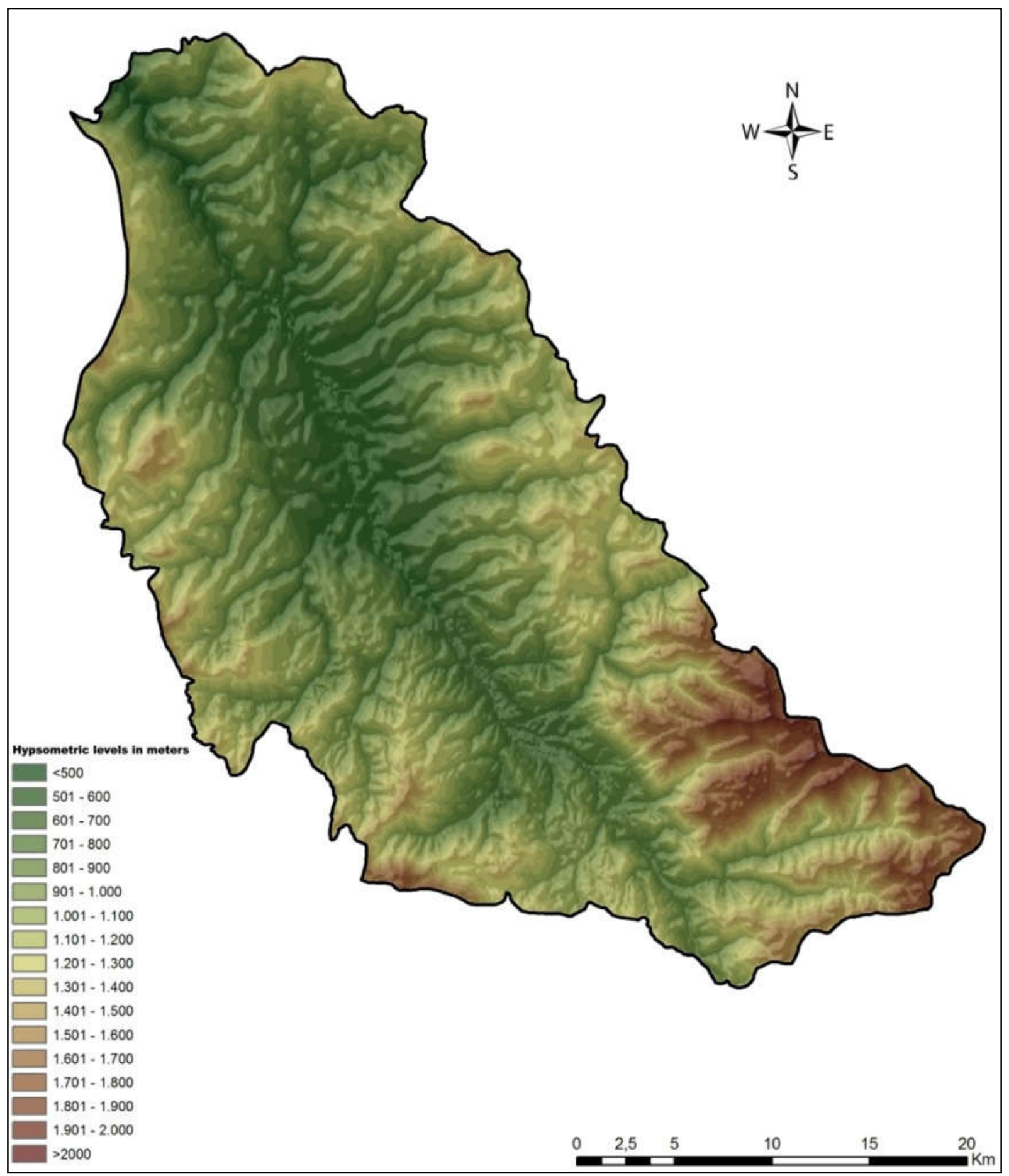

Figure 1 - Hypsometric levels in Uskopaljska Valley

This can cause extreme drying out of the soil. Conversely, top soils lose heat rapidly through free erasure during the night. Due to this, the ground at high altitude is dried and frozen, thus creating hazards to agricultural activities. At higher relative altitudes, harvest depends on how important and valuable crops are to humans and livestock. Sometimes the majority of them is necessary, although crops are not yet fully mature.

The increase in the quantity of rainfall with altitude is not less important for the agriculture than temperature reduction. As the capacity of moisture content in the air varies and is directly related to its temperature, and as this is reduced adiabatically in the going-up air, hilly and mountainous areas have heavy rainfall as is the case in the Uskopaljska valley [15]. 
Consequently, to a certain height, agriculture is being hit by heavy rain and soil erosion. In places of the combination of high altitude and sufficient moisture appears snow that makes agricultural activity very difficult. At different altitude, the effectiveness of rainfall for agriculture varies on different slopes and their varying aspects. It is much more efficient on the side under the direction of wind. Similarly, the efficiency of agricultural production is relatively small on the sunny slopes due to increased evapotranspiration.

High altitude cause variations in the deployment of rainfall on the local as well as regional level. On the slopes under the direction of wind, rain is usually plentiful, and on downwind side much smaller; in certain situations even insufficient. Adverse effects can also have the orientation of mountains as for example when the mountain is oriented parallel with a similar air masses that are not condensed nor increased. The orientation of mountains not only blocks the winds but also drives them in a certain direction. Sometimes occasional winds could cause rain on some sides and form clouds, fog, snow and the like [13].

Slope structure. Slope structure of inclination appears as a limiting factor of crop production, and even the use of agricultural land. Arrangements and yields of agricultural crops, performance and efficiency of mechanization, irrigation, soil erosion intensity, etc., are to a large extent conditioned by this relief property.

Inclination of terrain is one of the most important characteristics of relief that affect agricultural use of space. Impacts of the inclination on agriculture are direct and indirect. The most obvious direct influence of inclination is in the form of obstacles to the cultivation and availability. The indirect impact of the site inclination is manifested in soil climatic modifications including position of impermeable layer, development of soils, air drainage and relative freedom from freezing. However, data on the inclination are available only in generalized form in view of the fact that they are taken from maps. For practical purposes, especially agricultural use, there is hardly any information available and that it is possible to know the importance of inclination site. One cannot ignore the fact that too steep and angled spaces cannot be cultivated due to inherited restrictions [12].

It is found that with the inclination increase, the sum of annual radiation on the northern slopes is reduced and on the southern is increased. Thus, the south and southwest exposure are extremely suitable for growing agricultural crops that require more heat and light. Simultaneously with the inclination increase grows solar radiation and the amount of moisture in the soil is reduced (table 1).

Table 1 - Annual sum of sun radiation on the sides of southern exposure [6]

\begin{tabular}{|c|c|}
\hline Slope & Radiation in Kcal \\
\hline $0-2^{\circ}$ & $90-110$ \\
\hline $2-7^{\circ}$ & $110-130$ \\
\hline $7-15^{\circ}$ & $130-150$ \\
\hline over $15^{\circ}$ & More then 150 \\
\hline
\end{tabular}

It is a known fact that with the increase of slope inclination the use of even very simple machinery becomes difficult. Even more, there is hardly any information on how cultivation costs vary with the inclination nor is it possible to list all the practical constraints for safe operations with different mechanization equipment. Still, much depends on the present economic situation and the way equipment is used, for example, one-way plowing is possible with a track tractor on almost any slope covered with soil [2]. However, farmers will not prefer steeper slopes if there are alternatives. Steeper slopes are generally bypassed and processed only if there is population pressure (as for example in India).

Animal husbandry can equally be subjected to the impact of a sloping site. For animals it is difficult to move around and graze in areas with steep slopes. Under such conditions, they quickly get tired and require additional feeding with forage. Possibly, the total production of dairy business will be most affected. Therefore, goats, sheep and other small livestock are an ideal replacement for the relatively steep slopes.

With increasing inclination, the quality and productivity of agricultural machines are reduced and the consumption of labor and resources is increased. At the same time it 
increases the intensity of erosive processes. Therefore, the slope structure of inclination appears as a limiting factor in the profitability of production [11].

Evaluating the slopes of inclinations, on the basis of the intensity of erosive processes and application possibilities of mechanization in the Uskopaljska valley one can distinguish the following categories of space:

1. Spaces suitable for processing:

I category $0-3^{\circ}$ - very intensive processing;

II category $3-6^{\circ}$ - intensive processing;

III category 6-9 - moderate processing;

IV category $9-13^{\circ}$ - limited processing.

2. Spaces unsuitable for processing:

$\checkmark$ category $13-19^{\circ}$ - intensive grasslands;

VI category $19-35^{\circ}$ - extentsive grasslands;

VII category $35-45^{\circ}$ - forests;

VIII category over $45^{\circ}$ - forests and wildlife [10].

Taking into account the previous classification of limit values of inclination slopes, then the basic criteria for planning of rural areas, as well as the existing layout of agricultural production in the Uskopaljska valley, according to the use-value there are following areas:

1. Zone with the areas favorable for crop-vegetable and fruit production with border slopes up to $13^{\circ}$ except in the case of high mountainous regions. Within this zone, two subzones can be distinguished:

a) Sub-zone of intensive crop-vegetable and fruit production with slopes up to $6^{\circ}$. These are spatial units in which it is possible to use different machines for individual crops. They include mainly alluvial plains of rivers and river terraces and only sporadically hillside slopes in lake sediments.

Nearly flat to gently ruffled areas with adequate drainage to $3^{\circ}$ do not represent a problem for cultivation. They have ideal conditions for any type of agriculture, and if there is an irregularity in the form of small dikes or some undulations, it may be eliminated by terracing. Machinery can be used without problems. Operational costs are much lower in these areas. Almost the entire arable areas fall into this category. Torrent flows and floods can cause serious damage to the slopes by the process of waterlogging.

Ruffled slopes of $3^{\circ}$ to $6^{\circ}$ do not represent a serious obstacle to cultivation unless there are some irregularities on the surface. As slopes are moderately steep, drainage problem is not noticable. However, occasional flooding can cause soil erosion. Overall, the extent of cultivated space on these slopes for agriculture declines and more terraced fields begin to appear. The processes of erosion on these slopes are very few expressed. The areas with these slopes encompass more than $1 / 3$ of the Uskopaljska valley (33.8\%) (table 2).

Table 2 - Slope structure in Uskopaljska Valley

\begin{tabular}{|c|c|c|}
\hline Slope & Area in $\mathrm{km}^{2}$ & \% from total area \\
\hline $0-3^{\circ}$ & 255.6 & 23.51 \\
\hline $3-6^{\circ}$ & 111.9 & 10.30 \\
\hline $6-13^{\circ}$ & 239.8 & 22.06 \\
\hline $13-19^{\circ}$ & 198.6 & 18.27 \\
\hline over $19^{\circ}$ & 281.3 & 25.86 \\
\hline
\end{tabular}

b) Sub-zone with the areas that are conditionally favorable for intensive crop-vegetable and fruit production with the slopes of $6-13^{\circ}$, encompasses more than $22 \%$ of the studied area. On these slopes it is necessary to take anti-erosion measures (contouring, terracing, etc.). Increasing slope inclination reduces the possibility of using all the agricultural machines, as well as productivity. This category can be characterized as very steep. The slopes with an inclination of $11^{\circ}$ are the safest limit for the soil to be processed. Thus, the spatial units with favorable conditions for crop-vegetable and fruit production include more than half of the total area of the Uskopaljska valley (55.8\%). 
2. Zone with the areas favorable for intensive meadow-pasture forage production with slope inclines of $13-19^{\circ}$, comprises $18.3 \%$ of the total area of the Uskopaljska valley. In this region it is possible to use machinery that is used for the production of forage. In addition, vegetable and fruit production is possible in this zone with the use of terracing, unless it is a high mountain region. In such a moderately steep slope areas, access to land is limited. Cultivated landscapes are rapidly decreasing due to obstruction. Terraced fields with terraces that are parallel to contours of the slopes are typical for this region. Their length is often three to four times greater than their width. There is a direct link between their width and slope inclination.

3. Zone with the areas suitable for forest ecosystems with inclination slopes over $19^{\circ}$ covers $25.8 \%$ of the total area of the observed region. These spaces are partially conditionally favorable for meadow-pasture production (slope angles up to $35^{\circ}$ ). However, the use of machinery for the production of forage crops is very limited. If there is no grass cover in this area, there are intensive erosion processes. Intensive erosion processes that were taking place here as well as the value of soil cover suggest that this zone should be used mainly for forestry. Field research in the area of Uskopaljska valley indicates that such inclined slopes are partly developed as meadows and pastures and, where conditions allow, there are grown grains or vegetables. The slopes with an incline over $35^{\circ}$ are practically unsuitable for cultivation because they are very steep (figure 2).

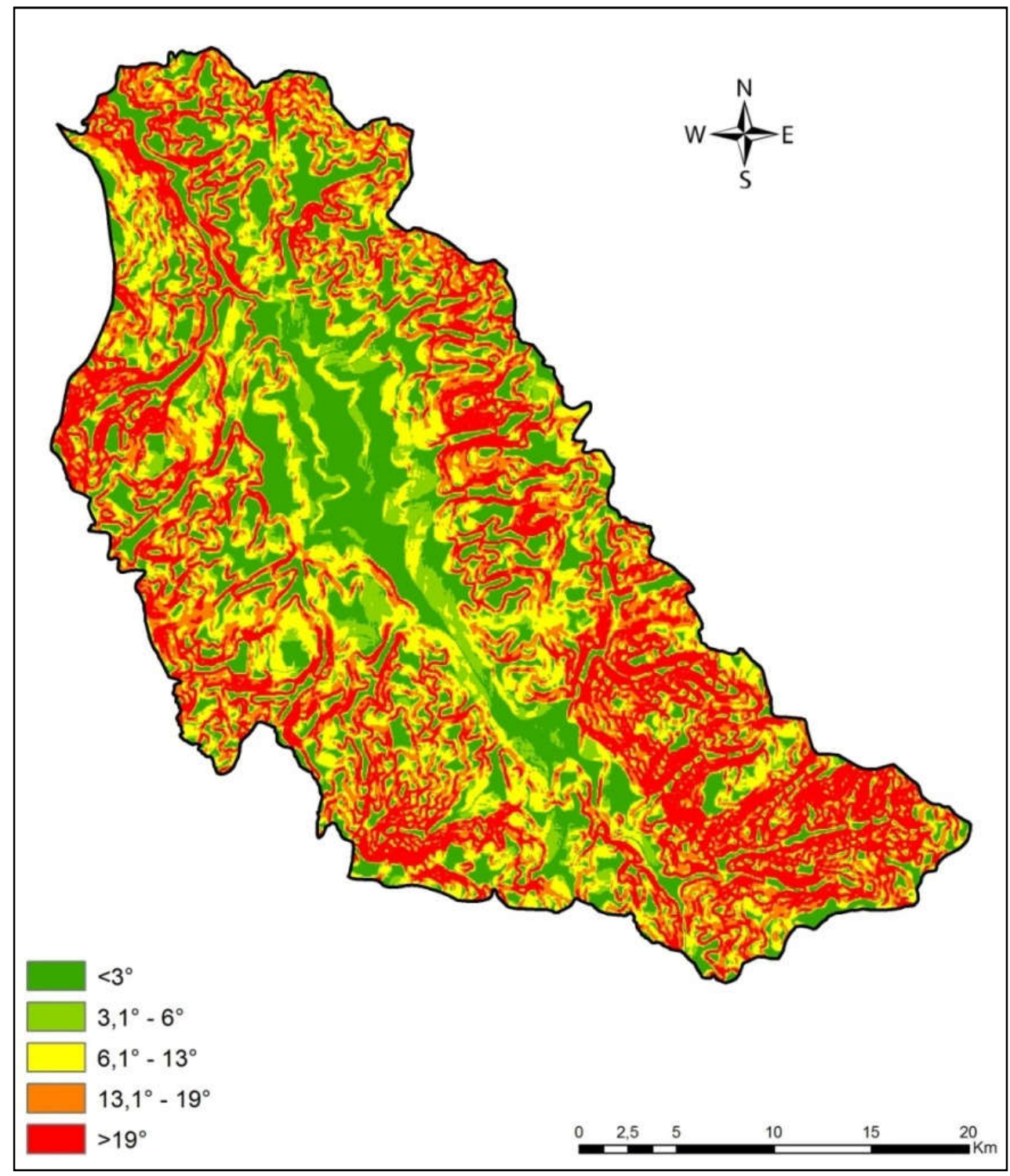

Figure 2 - Slope structure in Uskopaljska Valley 
Overall, the slopes of truncated valleys are often too steep to be able to cultivate; paradoxically, valley bottoms are often marginalized because of deep water tables. On moderately steep slopes of mountain areas both poor drainage and unfavorable climatic conditions limit the development of agriculture. That is why adaptation of such slopes is necessary during cultivation. For example, it should be adapted so as not to endanger the land cover. Slope areas have to be cultivated under wet conditions otherwise the ground will be under the influence of severe erosion. Moreover, it is technically feasible to cultivate moist soil with plow discs than with conventional plows. The gentler rolling slopes, the greater potential for agricultural development of an area. Availability is the most potent factor in the agricultural land use in hilly-mountainous areas on any slope or elevation while the unavailability of a place can make all the development efforts futile. The availability, according to Wingo [17], is a relative quality which refers to any space in interrelation with the transport system. The term availability is used in a relative sense because it mostly depends on many variables of which the most important is economic development of the region.

For lowland areas, there are two main elements of availability: distance and time; while for hilly and mountainous areas, there are different elements such as distance, inclination, diversity, and the time and energy spent by farmers while moving from place of residence to the field. Therefore, the first three elements in the latter case are related to the absolute aspect of availability as they are quantifiable while others are related to the relative aspect. Asthana [1] concluded that the slope inclination makes walking pretty exhausting. He tried to establish a precise mathematical relationship between the slope inclination and the distance that a man passes. Thus, he calculated that a man at a normal pace can move about $8 \mathrm{~km}$ per hour on flat areas, while in areas with a slope of 15 degrees one can exceed 1.84 kilometers an hour. Hence, it can be concluded that the time and energy spent by farmers on a journey from the residence to the field increase with the slope of a terrain, which leads to a lower intensity of agricultural use. However, field observations show that, on flat areas of the alluvial plain of the Vrbas near the city of Bugojno and the alluvial plain of the Oboračka river, farmers on the average cross only about $5 \mathrm{~km}$ at a normal pace per one hour. In contrast, farmers on the hillsides and hills along the Vitina river in the east and the Prusačka river on average cross $2.2 \mathrm{~km}$ per an hour which is considerably different from Ashtana's calculation.

An easy access is essential especially for growing vegetables and fruits in hillymountainous areas although technological development has rather reduced its importance in recent years. Milk, meat and so on cannot be kept for a long time and therefore efficient transport to market is essential. Likewise, in the case of vegetables and fruit, freshness is equally important aspect. Especially big problems with the access to their farms have farmers in the southern and southeast part of the Uskopaljska valley in the municipality of Gornji Vakuf where the slopes of the terrain are most pronounced.

Exposure of sides. Topographic surface exposure affects modification of microclimate elements, but does not have the character of limiting factors of agricultural production. The impact of the exposure is reflected in the deployment of crops, the yields, the type of vegetation and the like. From the aspect of agricultural production, longer sunny exposure is more valuable. According to importance, the following disposition can be taken: the south, west, east, north [14].

Differences in the amounts of direct radiation between the opposite exposures (northsouth) are more pronounced with increasing the slope. At the same slopes of inclinations, temperature difference between sunny and shady slopes of the ground layer of air can reach $6-7^{\circ} \mathrm{C}$, and at a depth of $1 \mathrm{~cm}$ in soil up to $6^{\circ} \mathrm{C}$ [16]. Accordingly, the sunny sides are heated more strongly, they dissolve snow more quickly and have greater evaporation. For this reason, on the southern exposures spring processing, sowing and ripening come earlier than on the northern. Moreover, the western and eastern exposures provide more favorable conditions for the development of agricultural crops than the northern.

In the Uskopaljska valley, it can be noted that the unexposed areas and favorable exposures are dominant in the spatial units where also other natural conditions are suitable for crop production. The alluvial plain of the Vrbas and major tributaries as well as the river 
terraces or areas of intensive vegetable production have the characteristic of the unexposed areas and southern exposures.

The unexposed areas cover the largest expanse in the alluvial plain of the Vrbas and lower parts of the alluvial plains of the Oboračka river, Drvetinska, Čehajićka river and Bistrica. The unexposed areas are also represented by the production of vegetables in greenhouses. Total unexposed areas cover about $6 \%$ of the surface. Besides, the depression hills in lake sediments as well as the hills in the crystalline schists are characterized by good exposure of sides. The relief of the hills is dominated by the southern, eastern and western exposures (table 3 ).

Table 3 - Exposure of sides in Uskopaljska Valley

\begin{tabular}{|c|c|}
\hline Exposure & \% from total area \\
\hline Unexposed & 6.0 \\
\hline N & 11.6 \\
\hline NE & 13.0 \\
\hline E & 11.0 \\
\hline SE & 10.6 \\
\hline S & 11.3 \\
\hline SW & 11,7 \\
\hline W & 12.5 \\
\hline NW & 12.3 \\
\hline
\end{tabular}

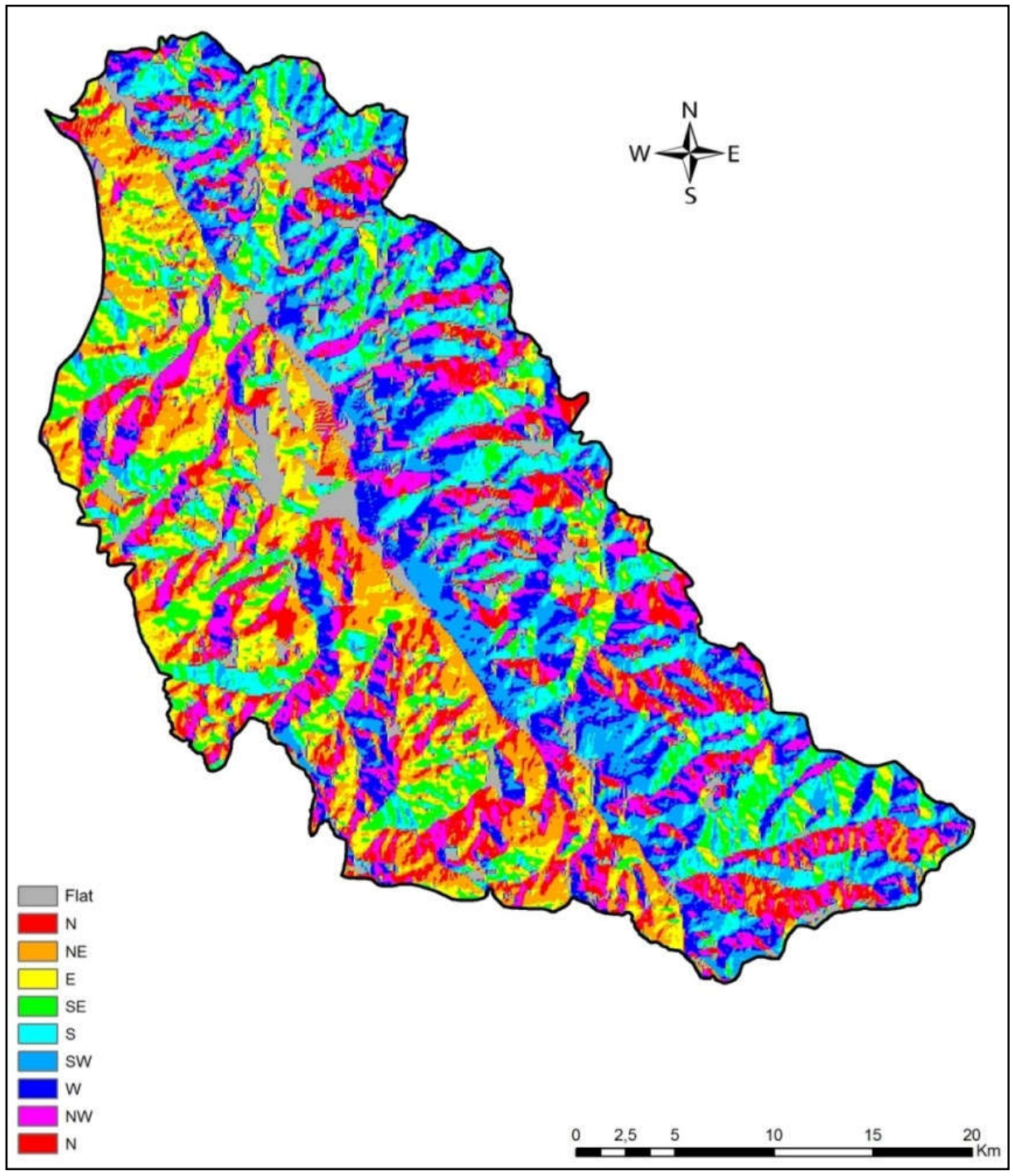

Figure 3 - Exposure of sides in Uskopaljska Valley 
Peripheral hills on the right side of the confluence of the Vrbas have a very favorable exposure, where it is dominated by the western and southern exposures that are extremely suitable for fruit production. The circumferential hills on the left side of the confluence of the Vrbas has a major presence of the eastern exposures while the area of Duboka river is characterized by the western exposures and is very suitable for crops and fruits.

Thus, the complete right side of the confluence of the Vrbas river with the alluvial plains, river terraces and hills are very dominated by the southern and western exposures, while opposite them the left side of the confluence and its agricultural production are exposed mostly to the east and northeast. Exposure of the mountain rim is determined by the direction of the river valleys and the presence of flattened fragments and plains with the domination of southern exposures on the east, and eastern exposures on the west (figure 3 ).

Influence of the direction of slopes on agricultural land use is inseparable from other natural conditions because, at any altitude, air at the macro and micro level varies at different slopes. The effects are indirect through modification of climate and are primarily of local character. There are monthly differences, differences in maturation of crops between sunny slopes and shady slopes. Variations in slope-aspect within the same farm can prolong the season grazing and thus determine the early and late grazing. There is a significant difference in the agricultural use of the area between the sunny (south south-east and south south-west) and shady slopes (north north-east and north north-west), and pretty much between the partly sunny (east and south- east and west south-west) and partly shady slopes (east north-east and west north-west) in the area of Uskopaljska valley.

Relief energy. For determination of the spatial intensity of erosion, great importance has the relief energy map. The term relief energy means the parameter of vertical diversity of relief and represents potential energy of a particular terrain defined by vertical difference between the highest and lowest point within the observed unit surface of terrain [5].

Intersected relief (relief energy) of an area determines the value of agriculture terrain. It is a by-product of comparative assessment of hypsometrical levels, absolute relief, relative relief etc. in any space. Unlike hypsometrical levels, regions of absolute relief are obtained by combination of individual peaks and chains that represent the highest points. They represent homogeneous belts of high relief. However, this is not very helpful in understanding and explaining the variation in agricultural use of areas because the absolute altitude does not give an idea of the width of relief.

Relative relief on the other hand is an index of sharpness because it indicates the difference between the highest and lowest heights that exist in the common area. There is always a scope for significant variations along gullies and watercourses but if the amplitude in the relative regional relief is bigger, intersection is seen to vary significantly from place to place. That is why it can be concluded that when diversity of relief grows, agricultural potentials are reduced [3], because when a relief is locally more diverse, there is a decrease in the effective value of agriculture space. A common feature in hilly-mountainous areas of the Uskopaljska valley is that with the increase of relief diversity, dairy farming is automatically replaced with herds such as sheep, goats and the like.

Table 4 - Relief energy in Uskopaljska Valley

\begin{tabular}{|c|c|c|}
\hline Relief energy $\left(\mathrm{m} / \mathrm{km}^{2}\right)$ & Area in $\mathrm{km}^{2}$ & \% from total area \\
\hline $0-5$ & 10.1 & 0.93 \\
\hline $5-30$ & 24.8 & 2.28 \\
\hline $30-100$ & 128.4 & 11.81 \\
\hline $100-300$ & 657.0 & 60.42 \\
\hline $300-500$ & 252.3 & 23.21 \\
\hline over 500 & 14.6 & 1.35 \\
\hline
\end{tabular}

By analyzing the relief energy maps of the Uskopaljska valley it is concluded that areas with a greater relief dissection represent regions where increased soil erosion may arise. They cover $24.56 \%$ of the area or 266.9 square kilometers (table 4). These are the areas of the mountains of Vranica in the southeast, Radovan, Rudine, Kalina in the east, Komara in 
the northeast, Šatara, Sokolina, and Pejakovac and Vukovi in the north near the Vrbas river, Crni Vrh, Šuljage in the west, Stožer and Raduša in the southwest and south (relief energy more than $300 \mathrm{~m} / \mathrm{km}^{2}$ of the area). This is also confirmed by field studies that have been conducted for the purpose of making this work.

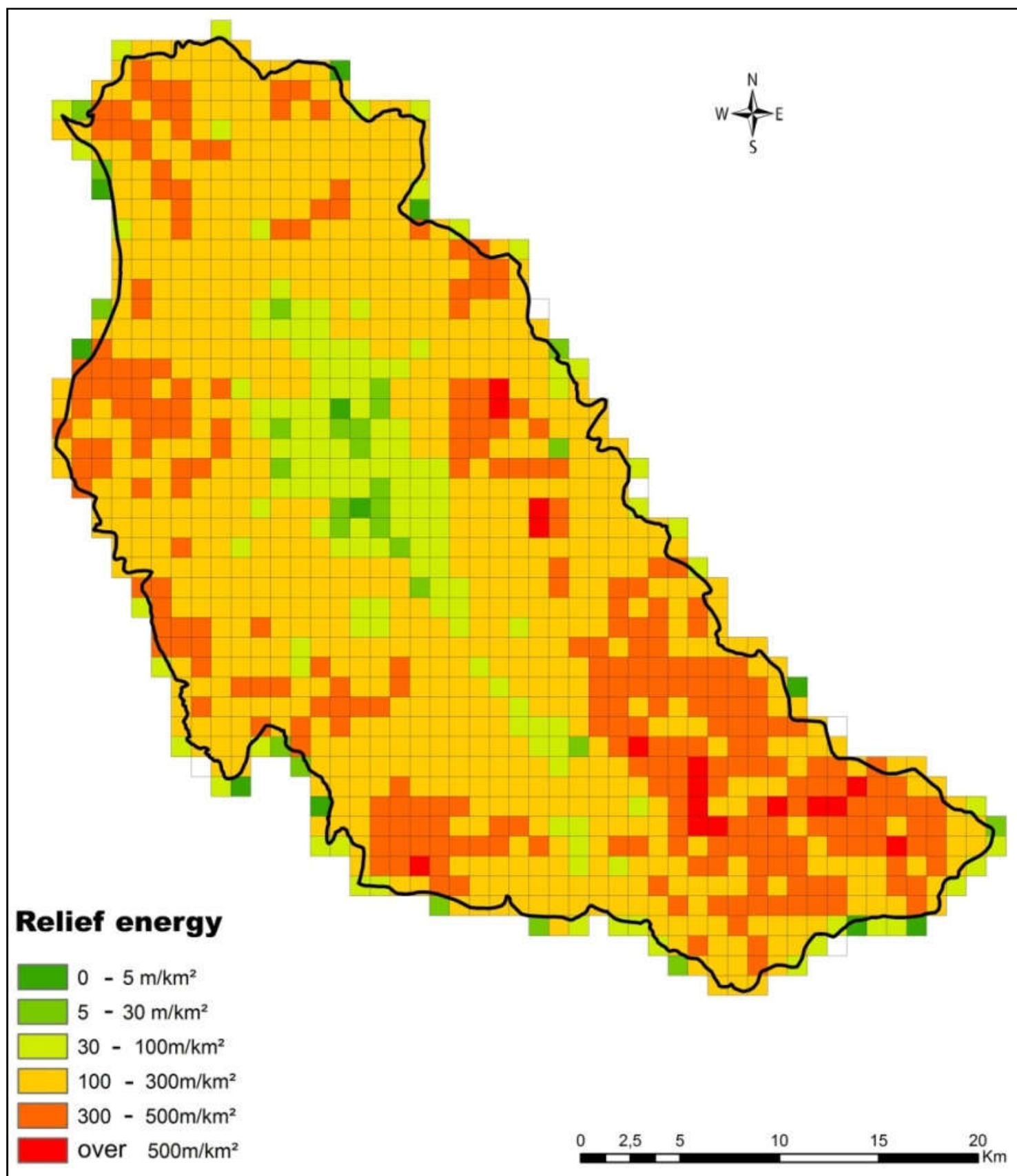

Figure 4 - Relief energy in Uskopaljska Valley

The most intensive accumulation occurs along the Vrbas river from Gornji Vakuf expansion to Donji Vakuf expansion, where relief energy is up to $5 \mathrm{~m} / \mathrm{km}^{2}$ as well as in the valleys of the major tributaries of the Vrbas, especially the Prusačka river, Poričnica, Veseočica in the west, Trlice in the south and the Čehajićka river, Drvetinska river, Vitina and Vileški creek in the east. The spaces with the most intense accumulation cover just over 10 $\mathrm{km}^{2}$ of the area. The most widespread are the areas with the relief energy of $100-300 \mathrm{~m} / \mathrm{km}^{2}$ which cover an area of 657 square kilometers, or $60.4 \%$. They are located mainly in the zone above $650 \mathrm{~m}$, mostly in the west and east while the mountainous southwest is characterized with high relief energy (Vranica mountain) (figure 4). 


\section{CONCLUSION}

The area of the Uskopaljska valley is extremely suitable for crop production, but is also rich in forest areas which are located on the sides of the mountain rim and rich grass fields. From the aspect of agricultural production, alluvial plains are the most important form of relief in the Uskopaljska valley. The hilly zone with the domination of alluvial plains $420-600 \mathrm{~m}$ above sea level and the hilly zone with the dominance of depression hills covers altitudes from 601 to $750 \mathrm{~m}$ above sea level toghether covers approximately $23 \%$ of the observed area. This zone is related to intensive agricultural production in the Uskopaljska valley. Favorable slope structure favorable climate, soil and other natural conditions in this zone allow diverse crop production.

Total unexposed areas and sides with south exposure covers about $17 \%$ of the surface. The relief of the hills is dominated by the southern, eastern and western exposures. Looking at the local scale, energy relief can analyze the intensity of development of exogenous processes in a way that areas with the greatest energy are at the same time also places where you can expect the emergence of increased erosion, and areas with low energy with a possible increased accumulation. Map of relief energy practically analyze predisposition of terrain for the emergence of erosion or accumulation in Uskopaljska valley.

\section{REFERENCES}

1. Asthana V. Landforms and settlements in Almora and its environs. Doctoral Thesis, Banaras Hindu University, 1968. p. 62-74.

2. Coppock J. An Agricultural Geography of Great Britain. G.Bell \& Sons, London, 1971.

3. Dhillon S. Changing pattern in agricultural land use in Mahasu District. Doctoral Thesis, Kurukshetra University, Kurukshetra, 1973. p.70-82.

4. Dinić J. Ekonomska geografija. Ekonomski fakultet. Beograd, 1992. p. 122

5. Dragičević S. Kvantitativna analiza reljefa na primeru sliva Kolubare. Globus. Srpsko geografsko društvo, Beograd, 2002.

6. Finke L. Landschaftsokologie. Holer, Braunschwaig, 1986.

7. Gekić H. Geografske osnove pojoprivredne proizvodnje u Uskopaljskoj kotlini. Doctoral Thesis, Department of Geography, Faculty of Science, University of Sarajevo, Sarajevo, 2016. p. 30-33.

8. Gekić H, Bidžan A. Influence of Water Resources on Agriculture in Uskopaljska Valley. Journal of Global Resources 1 (1), Institute of Sustainable Development, Environmental and Scientific Research, Jaipur, India, 2015. p. 23-38.

9. Gekić H, Bidžan-Gekić, A. Urbanization in Bosnia and Herzegovina: A case study of Uskopaljska Valley. Theory and Practice 6, Lancaster, USA, 2016. p. 147-154.

10. Radman V. Mehanizacija kao faktor rejonizacije ratarske proizvodnje i kategorizacije upotrebne vrijednosti zemljišta na nagnutim terenima. Zemljište i biljka, 33 (2), Beograd, 1984.

11. Rajović $\mathrm{G}$. Assessment of land use and characteristics of relief valorization morphometric agriculture north-east Montenegro. Analele Universitatii din Oradea-Seria Geografie, No. (1), 2011, p. 105-116.

12. Sharma R. Applied Geomorphology and Agriculture. The Associated Publishers, Ambala City, Haryana, 2008. p. 44-52.

13. Singh J., Dhillon, D. Agricultural Geography. 3rd Edition. McGraw Hill, New Delhi, 2004. p. 47-60.

14. Spasojević M. Ekonomsko-geografska valorizacija prirodnih uslova i resursa sa posebnim osvrtom na Ponišavlje. Doctoral Thesis, Prirodno-matematiçki fakultet, Beograd, 1989.

15. Symons L. Agricultural Geography. G.Bell, London, 1967.

16. Volf M., Dimitrovskij, J. Geografija mirovog hazajstva. Misl, Moskva, 1981. p.34-37.

17. Wingo L. Transportation and Urban land models in Geography. Methuen, London, 1961. 